\title{
Life-World, Sub-Worlds, After-Worlds: The Various 'Realnesses' of Multiple Realities
}

\author{
Ruth Ayaß ${ }^{1}$
}

Published online: 16 February 2016

(c) The Author(s) 2016. This article is published with open access at Springerlink.com

\begin{abstract}
This paper will discuss the correlation between the world of everyday life, finite provinces of meaning, and religion. To this end, the paper will start out by explaining Schutz' considerations on "paramount reality" of the world of everyday life as well as the theory of "multiple realities" and "finite provinces of meaning". Schutz' considerations will then be elaborated upon and taken a step further in a discussion of the various 'realnesses' of the multiple realities. Special attention will be paid to a finite province of meaning only mentioned in passing by Schutz: religion. The paper will first analyze the special features of religion as a finite province of meaning and highlight the correlation it enters with the world of everyday life. Subsequently, hereafter and paradise conceptions will be described as "ultimate provinces of meaning," and it will be shown how their realnesses connect to the world of everyday life. Finally, the "fundamental anxiety" will be studied as the motor of the relevance structures of the world of everyday life, the finite provinces of meaning as well as the hereafter conceptions.
\end{abstract}

Keywords Finite provinces of meaning - Multiple realities · Alfred Schutz · Religion · Sub-universes · Paradise · After-world

\section{Introduction}

It is beyond doubt that among all possible realities-dreams, sleep, imagination, and many more - the world of everyday life takes center stage. It is in this world that we live, act, are born and die, work, and live our daily lives. The detailed phenomenological analysis of this world of everyday life as a basis of and a space

Ruth Ayaß

ruth.ayass@aau.at

1 Institut für Kulturanalyse, Universität Klagenfurt, Universitätsstraße 65-67, 9020 Klagenfurt, Austria 
for our acting is owed to Alfred Schutz. However, the everyday life-world also serves as a place which contains gateways and transitions to other realities. That is, when sleeping, dreaming, or fantasizing, we temporarily exit the reality of the world of everyday life. For the description and the analysis of this other reality, Schutz has coined the term "finite province of meaning". Finite provinces of meaning make realities of their own, while the totality of finite provinces of meaning-together with the everyday world-constitutes the universe of "multiple realities". According to Schutz, there are "several, probably an infinite number of various orders of realities, each with its own special and separate style of existence" (1962a: 207). At a fundamental level, the present paper is a continuation of Schutz' considerations. Taking Schutz' ideas a step further however, it will be concerned with the various 'realnesses' of just these multiple realities. It will highlight, that is, the ways in which these various realities differ in their internal structures and the particular mutual correlations they can enter. Special attention will be devoted to something Schutz mentions only in passing: the finite province of meaning of religion. At an initial stage, a range of questions are raised: to what extent do realities constituted by religion differ from other closed provinces of meaning? What are the correlations between religion and those other provinces of meaning? And, crucially, in what ways do these 'realnesses' of the finite province of meaning of religion impact the world of everyday life?

The present essay will start out with a summary of Schutz' description of the world of everyday life (Sect. 2) and distinguish the world of everyday life from the realnesses of the closed provinces of meaning (Sect. 3). Section 4 will then be concerned with the particular concepts of alternative realities featured by religions, i.e., conceptions of paradise and hereafter, which will be analyzed as "ultimate provinces of meaning". The primary question to be asked here is which influence these concepts of a hereafter have on the world of everyday life.

While Schutz (and much of the literature that emerged from his work) primarily determines finite provinces of meaning based on the predominant cognitive style, the present paper addresses the everyday consequences of the interaction of the different provinces of meaning. The following considerations are concerned much less with the specific subjective experiences an individual might have in closed provinces of meaning, than with the connections which the various provinces may form with the world of everyday life, and thus with the 'real' consequences and repercussions these inner experiences have for the everyday life-world.

\section{The Reality of the Everyday Life-World as a Hub for the Multiple Realities}

As is well-known, the world of everyday life and its structures are a central aspect of Alfred Schutz' considerations. The analysis of this subject matter pervades his entire avre-from Der sinnhafte Aufbau der sozialen Welt (1932, translated in 1967 as The Phenomenology of the Social World by George Walsh and Frederick Lehnert) to the posthumous publication The Structures of the Life-World (Schutz and Luckmann 1973, 1989; translated by Richard Zaner and Tristram Engelhardt). 
Within the life-world, the world of everyday life is a central point of reference. It is therefore unsurprising that Schutz describes the multiple realities on the basis of the reality of everyday life, using features of the everyday life as a starting point of his presentation. According to Schutz, this everyday reality is characterized by the following features: (1) From its outset, the world of everyday life is an intersubjective world, i.e., within it, man takes action and encounters Others. Man experiences this world as "experienced and interpreted" by his predecessors (1962a: 208). (2) Man's stance in this world is marked by his natural attitude. By this attitude, his environment appears to him as unproblematic, simply given, and undoubted. (3) It is determined by the pragmatic motive, i.e., the world is perceived and interpreted as something which can be altered by human action, but also as something which in turn influences our action. (4) The world of everyday life is determined by a certain tension of consciousness as well as an attention to life. In everyday life, that is, man is in a state of wide-awakeness, his attention is directed at this world and he experiences it as unquestionable (1962a: 213). It is given to him as self-evident, pushing aside any possible doubts and confusions.

Another characteristic feature of the world of everyday life is its specific temporal structure. Anything that happens in this world is experienced as events within an outer time (Schutz refers to this as "objective" or "cosmic" time, 1962a: 215). Inner time, on the other hand ("durée" in Henri Bergson's sense), is 'my" time, indivisible by its nature. Through my memories, it brings me into contact with my past and, through my planning and intentions, provides a connection with my future. For Schutz, the coincidence of inner and outer time produces the "vivid present" (1962a: 216). This shared present is the space in which face-to-face relations, called "we-relations" by Schutz, can arise. Their characteristic feature is the abundance of symptoms with which the Other is given to me (and I am given to him), i.e., I can see him and hear him (and vice versa), I can take action toward him (and he towards me), in other words we share time and space. "We both, I and the Other, experience the ongoing process of communication in a vivid present" (Schutz 1962a: 219). For Schutz, all other relations are derived from these immediate relations, featuring the other merely "as a partial self" (1962a: 221), e.g., as the originator of an action whose emergence I cannot witness, but of whom I can only see the consequences. The world of everyday life is segmented, it has structures. It is divided into sections in which I have the power to achieve something by taking action and sections in which I do not have this power. Schutz uses the term "working" to distinguish mere (covert) thinking from overt action involving actual physical movement (1962a: 243). This world of working encompasses the section with which we can come into contact and which we can act upon, as opposed to the section which we can merely see. "[...] the world of working is structurized in various strata of reality" (1962a: 223). What Mead describes as "manipulatory area" Schutz takes to be the "core of reality" (1962a: 223). Another term used by Schutz is "world within my reach," by which he refers to the world of working in the strict sense as well as anything that can be perceived-i.e., heard, seen, etc.-within the capacity of human senses.

This "world within reach," as it were, migrates with man and relocates itself according to his actions. Changes to the zero-point in my coordinate system are 
changes to my reach: things previously within reach have now moved out of reach, while things previously unreachable are now within reach. This is a point of intersection of man's reach and the temporal structure. Aside from the world that is presently within my reach, there is a world within reach which I can go back to and a world which will be in reach in the future. In this respect, Schutz makes a distinction between two potentialities: the "world within restorable reach" (1962a: 224), which refers to a world previously within my reach, and the "world within attainable reach" (1962a: 225), i.e., a world within reach in the future. It is possible to turn the world within my attainable reach into a world within my present reachthis mostly involves some form of spatial movement and generally takes time.

This temporal and spatial structure of the world of everyday life affects not only my respective reach, but also my access to Others. Schutz, again, distinguishes between a temporal and a spatial level. Time is shared with both consociates and contemporaneous fellow-men. However, my consociates occupy the same vivid present as me and hence partake in the same time and the same space. They are thus given to me in their physicality and their abundance of symptoms. This is not the case with mere contemporaneous fellow-men, whom I can experience only through mediation, e.g., when I see footprints in the snow or when I receive a letter. The transitions are gradual and occur continuously. My consociate of just a moment ago can quickly become a contemporary and vice versa. The greater the distance between me and my contemporaneous fellow-men, the more I experience them as typified. As for my predecessors and my successors on the other hand, there is no shared present at all. Flesh-and-blood experience of them is impossible even if they once lived, or will live, in the same space as me. They are not available for interaction, yet they can influence my actions (my predecessor may have bought the property I now live on) and I can attempt to have an impact on my successors (I can build a fountain for them on the property).

In this world of everyday life, two idealizations which Schutz takes from Husserl's Formal and Transcendental Logic (1969: § 74) come into play: the idealization of "and so on" and the idealization of "I can do it again". In his natural attitude, these two idealizations have a crucial significance for man "(...) namely, that I may continue to act as I have acted so far and that I may again and again recommence the same action under the same conditions" (1962a: 224). As long as the world continues to go unquestioned, man takes it for granted and treats it as a given. The two idealizations make an essential contribution to the "epoche of the natural attitude," in which man willingly accepts the world for what it is, suspending any disbelief "that the world and its objects might be otherwise than it appears to him" (Schutz 1962a: 229). For Schutz this indubitable world of everyday life constitutes what he calls "paramount reality" (1962a: 226), a term borrowed from William James (1890)—clearly demarcated by its properties from all other realities and significantly different in its nature. So fundamental is its experience that Schutz chooses to describe it as the "archetype of our experience of reality," emphasizing that "[a]ll the other provinces of meaning may be considered as its modifications" (1962a: 233). 


\section{The Realities of Finite Provinces of Meaning}

\section{Schutz' Notion of the "Finite Province of Meaning"}

From this archetype Schutz derives his descriptions of the other realities. ${ }^{1}$ The notion of provinces of meaning stems from the concept of "sub-universes" developed by William James in Principles of Psychology (1890), in which he speaks of "many worlds". Declaring that " $[\mathrm{t}]$ he total world of which the philosophers must take account is thus composed of the realities plus the fancies and illusions" (1890: 291), he refers to the latter as "sub-universes" or "sub-worlds". Among the most important sub-worlds, "each with its own special and separate style of existence," James counts the world of science, the world of madness, "the world of "idols of the tribe'," and "the various supernatural worlds," including Christian notions of heaven and hell, Hindu mythology, but also mythical narratives like King Lear and the Iliad (1890: 292f.).

From the very beginning of "On Multiple Realities," Schutz directly relates his theory to James' thesis of parallel, multiple realities, although he initially varies both the term as well as the argument it is meant to serve: "(...) we prefer to speak instead of many sub-universes of reality of finite provinces of meaning upon each of which we may bestow the accent of reality. We speak of provinces of meaning and not of sub-universes because it is the meaning of our experiences and not the ontological structure of the objects which constitutes reality" (1962a: 230).

It is the experience of these finite provinces of meaning that Schutz discusses in detail in "On Multiple Realities". Their primary characteristic feature is that they are void of the accent of reality of everyday life. Schutz specifically mentions the following provinces of meaning: "All these worlds-the world of dreams, of

\footnotetext{
${ }^{1}$ In essence, there are three texts in which Schutz details the finite provinces of meaning of multiple realities: "On Multiple Realities" (1962a) from 1945, which is central for this paper; "Symbol, Reality and Society" (1962c) from 1955, which studies the communication within and between finite provinces of meaning, also addressing the question of how communicating in and between provinces of meaning can take place. The essay on Cervantes' Don Quixote provides a more in-depth analysis of a specific fictional world ("Don Quixote and the Problem of Reality"; 1953 as a lecture, first English version 1964a).

In the essay on "The Stranger" (1964c) from 1944, although the text does not directly focus on multiple realities, the loss of certainty of the world of everyday life is discussed: "But these people do not understand that the stranger in the state of transition does not consider this pattern as a protecting shelter at all but as a labyrinth in which he has lost all sense of his bearings" (1964c: 105). Also for the manuscript on the "Reflections on the Problem of Relevance" (2011, written 1947 to 1951, published posthumously in 1970), the problem of multiple realities is central (2011: 96f.). Finally, a concise and brief depiction of finite provinces of meaning can be found in the first volume of "The Structures of the Life-World" (Schutz and Luckmann 1973: 22-34), as well as an elaborate discussion of the various forms of "transcendencies" ("small," "medium," and "great") and the "Boundaries of the Life-World" in the second volume of The Structures of the Life-World (Schutz and Luckmann 1989: 99-130).

Without a doubt however, the most important text for the present paper is "On Multiple Realities," on which Schutz began to work in 1936/1937 and which appeared in Philosophy and Phenomenological Research in 1945. On September 9, 1945, Schutz wrote to Gurwitsch, "I have devoted seven (lean) years to this essay. I don't know if it is good, but I do know that I can't improve it" (Grathoff 1989: 76f.) On Schutz' correspondence with Gurwitsch and Voegelin on this manuscript see Grathoff (1989: 75-77) and Wagner and Weiss (2011: 92-109).
} 
imageries and phantasms, especially the world of art, the world of religious experience, the world of scientific contemplation, the play world of the child, and the world of the insane-are finite provinces of meaning" (1962a: 232). Moving from one province of meaning to another is only possible by abandonment of the accent of reality of the first province. The point of origin is generally the reality of everyday life (although this is not a condition). A very typical finite province of meaning mentioned a number of times by Schutz is sleep and dreaming. This example provides a brief explanation of the properties and characteristics of finite provinces of meaning. Although the body of the sleeping person does not undergo any spatial changes and is observable for his contemporaneous fellow-men, the certainties of everyday life are no longer valid for the sleeping person in his dreams - in fact, they are canceled. Their place is taken by other conditions: In my dreams, I may do things I can obviously not do in everyday life (flying for example), but on the other hand, there are some things which go without saying in everyday life but which I cannot do in my dreams (running or escaping). In my dreams I may also meet people who are no longer alive (my predecessors). The time spent sleeping and dreaming is experienced as a time which does not correlate with the world of everyday life and which possesses its own temporal structure.

To describe the transition from one state to another, Schutz uses the word "shock" (1962a: 231), or "leap" (1962a: 232) making reference to Kierkegaard. It consists of "a radical modification in the tension of our consciousness, founded in a different attention à la vie" (1962a: 232). Every province of meaning experiences its own typical "shock" or "leap": "There are as many innumerable kinds of different shock experiences as there are different finite provinces of meaning upon which I may bestow the accent of reality" (1962a: 231). The examples given by Schutz are the transition into the world of sleep and dreaming, but also the inner transformations that take place in a theater when the curtain is raised or in an art gallery when closely studying a painting.

In his description of the constitution of multiple realities, Schutz provides detailed discussions of three of these provinces of meaning: the world of dreaming, the worlds of phantasms, and the world of scientific theory. He explains these three provinces of meaning in terms of the specific experience they involve. For example, there is an absence of the wide-awakeness we know from everyday-life experience as well as a mitigation of the tension of consciousness. Schutz concludes that " $\mathrm{t}] \mathrm{o}$ the cognitive style peculiar to each of these different provinces of meaning belongs, thus, a specific tension of consciousness and, consequently, also a specific epoché, a prevalent form of spontaneity, a specific form of self experience, a specific form of sociality, and a specific time perspective" (1962a: 232).

The knowledge and fear of one's own death, for Schutz, is the "basic experience" from which thanks to its domination of the natural attitude, the entire system of relevance is derived: "... the basic experience of each of us: I know that I shall die and I fear to die". Schutz refers to this elemental experience as "fundamental anxiety" (1962a: 228). All other relevancies of the life-world are derived from it. "It is the primordial anticipation from which all the others originate" (Schutz 1962a: 228). Fundamental anxiety is a determining element in 
the systems of relevance of the human life-world. It is the target of the suspensions which take place in the epoché of the natural attitude.

\section{Reading "On Multiple Realities"}

“On Multiple Realities" leaves readers with a number of questions, especially with respect to the interior structure and the logic of individual provinces and their comparability. It is for this reason that Schutz' discussion of multiple realities has been picked up repeatedly in the past decades. Among the first scholars to comment on Schutz' text in some length was Gurwitsch in Théorie du champs de la conscience (1964: 394-403). Discussing Schutz' notion of finite provinces of meaning, he then turns to the "existential problems" (1964: 401) of these provinces of meaning, which he subsequently studied using the term "order of existence" (1964: 404). Other authors, such as Goffman in Frame Analysis, provide only a rather cursory discussion of the term (1974: 6, fn 11).

On reading the texts which make direct reference to "On Multiple Realities," one becomes aware of the heterogeneity of the possibilities of further study presented by the text and the impossibility to systematize them. For instance, it may inspire a reading of Robert Musil's The Man Without Qualities (see Berger 1970), or a comparative analysis of the concept of finite provinces of meaning and Goffman's notion of frames (see Psathas 2014), or a comparison with Ortega y Gasset's notion of "being in one's self and being beside one's self" (see Hermida-Lazcano 1996). Other authors address the concept of provinces of meaning (with reference to Husserl: Marx 1970; with reference to Gurwitsch: Kassab 1991), or exemplify the concept by providing specific provinces of meaning, e.g., hallucinations (Endress 2003), religion (Nieder 2006), or art and literature (using Schutz' example related to Cervantes: Biemel 1983 and Endress 1998; discussing drama, poetry, and novel: Kersten 1998). Psathas (1998) applies the concept of finite provinces of meaning to the world of film and filmic realities. Some others are concerned with topics such as the correlation of provinces of meaning with communication (Knoblauch 1998), possible passageways between individual finite provinces of meaning (Sebald 2011), the specific correlation of provinces of meaning with rituals (Spickard 1991), with time (Flaherty 1987), with symbols (Dreher 2003), socialization and the world of adults and of children (Nasu 1999), or the role played by secularization in the pluralization of "meaning structures" and the question of which "feedback" finite provinces of meaning channel into the world of everyday life (Chojnacki 2012). While most authors concentrate on one aspect of finite provinces of meaning in general (Kersten for instance on cognitive style) or focus on one province of meaning in particular, Endress (2014) attempts further differentiation. He suggests that, since Schutz distinguishes between the various provinces of meaning on the basis of their predominant cognitive styles, it makes sense to differentiate between "various levels of reflexivity" (2014: 171). Based on a re-reading of Berger's essay on Robert Musil's The Man Without Qualities (see Berger 1970) and the novel itself, he distinguishes, depending on the degree of reflexivity, between first, second, and third-order finite provinces of meaning. 


\section{The Pragmatics of Finite Provinces of Meaning}

Schutz' conception of finite provinces of meaning primarily relies on their predominant cognitive style: "Hence we call a certain set of our experiences a finite province of meaning if all of them show a specific cognitive style and are-with respect to this style - not only consistent in themselves but also compatible with one another" (1962a: 230). In what follows, I will pursue a different avenue. My interest is with the pragmatic aspects of finite provinces of meaning in general. On the one hand, finite provinces of meaning possess distinctive realnesses which characterize them and separate them from one another. On the other hand, finite provinces of meaning incorporate themselves into, and have an effect on everyday life. On the face of it, Schutz clearly separates different provinces of meaning, emphasizing for instance that it is one thing to experience a finite province of meaning, and another to refer to it from the world of everyday life (1962a: 246). However, in his manuscript "Reflections on the Problem of Relevance," he implies that finite provinces of meaning are not necessarily as exclusive as had been suggested in "On Multiple Realities":

It was therefore an oversimplification to state as we did that we are living in different provinces of reality which we can interchange by a leap from one to another, and that the selection of one of them is the first step toward defining what is thematic and what is merely horizonal in our field of consciousness. In truth we are always living and acting simultaneously in several of these provinces, and to select one can merely mean that we are making it so to speak our 'home base,' 'our system of reference,' our paramount reality in relation to which all others receive merely the accent of derived reality (...). (2011: 98)

Given the ubiquity of finite provinces of meaning and man's ability to commute between them, how, then, can their concrete embedments and our everyday methods of dealing with them be described?

\section{Entering and Leaving}

The idealizations of the world of everyday life- "and so on" and "I can do it again" - are without meaning in a number of sub-worlds. The example of dreaming may illustrate this. Loss of the two aforementioned idealizations is an essential property of the world of dreams. Typically, inability to run or scream is experienced in dreams. At the same time, there is no need for the dream to be 'dreamy' or unrealistic in its internal logic, which is exemplified by nightmares which make the dreaming person startle from their sleep or perhaps even keep hold of them throughout the day. By the same token, sleeping and dreaming serve as valuable examples illustrating that many of Schutz' finite provinces of meaning are part of the basic anthropological equipment and can equally be accessed by anyone. Being asleep and having a dream do not come as privileges of a social elite-sleeping is something all of us do. Moreover, sleep is a province of meaning which cannot simply be 'triggered' (as anyone desperately trying to fall asleep will agree). 
One essential property of Schutz' sub-provinces of meaning is their simultaneity with the world of everyday life. Featuring their own temporal structure, they exist parallel to the world of everyday life. When sleeping or fantasizing, our environment continues to exist, although we do not participate in it and cannot be accessed by contemporaries. The progress of time is not halted. People awakening from sleep return to the world of everyday life, which in the meantime has continued to exist and has progressed with respect to cosmic time. In order to synchronize the subjective time spent in the sub-province of meaning, people sleeping, playing, or reading, typically need some form of re-orientation and frequently consult an objective chronometer (check the time, set an alarm, etc.). The transmigration from the world of everyday life into the finite province of meaning is not necessarily a result of a project of action or a 'fiat'. Not everyone trying to sleep, for example, is immediately successful, and the world of madness is not necessarily entered voluntarily. Returning from the finite province of meaning, for that matter, is frequently not a deliberate act either. Losing hallucinations is generally not something which the affected person can simply decree. And any schoolchild is familiar with the ordeal that is waking up (and getting up). Players, too (like people reading or making music), are often sunken so deeply into their world that the "leap" of returning into the world of everyday life is a form of waking up (and noticing that it has gotten dark in the meantime, that they have missed their stop, or forgotten a date). Thus, entering and exiting finite provinces of meaning is not always a question of free will or "choosing among projects of action" as Schutz describes it for the world of everyday life (1962b).

\section{Practices and Aids}

Some provinces of meaning can be entered without any additional means (e.g., sleep), while others require the use of aids (e.g., a state of ecstasy), or techniques which need to be learned and practiced previously (e.g., meditation). Note, however, that sleep is not only accessible without means-we can bring about and enforce sleep by using aids. The longing for the finite provinces of meaning can become so strong that it causes addiction to the aids allowing access to the state of sleep, trance, or ecstasy. The practices and aids which I need to learn or acquire in order to access the finite province of meaning and enter the desired state are obtained in the world of everyday life. For the instruction of techniques such as meditation, autogenic training, or yoga, there are offers inherent in our everyday lives through which trainers and professional providers share their knowledge. Drugs are traded on markets sometimes legitimized and taxed by the government (e.g., alcohol). Trafficking of these access aids may be legal or punishable by law (and can thus have severe consequences for everyday life).

Many experiences encountered in finite provinces of meaning are purposefully sought-after (e.g., intoxication, ecstasy), while others are tolerated or suffered against the will of the affected person (e.g., nightmares, hallucinations). One cannot help but notice that a large portion of the finite provinces of meaning appear to be of some attraction, and are pursued rather than avoided by many. Quite obviously, finite provinces of meaning can bring about sensations of happiness and satisfaction 
(which may serve as an explanation of their popularity). However, some can also cause a hangover as we return from them: re-entering into the world of everyday life leaves us with their painful after-effects-sometimes being disoriented, sometimes a bit out to lunch, sometimes just hung over. It seems as though humans regularly need to take time-outs from the world of everyday life-time-outs which serve specifically to disable certain conditions of everyday life (e.g., wide-awakeness). The finite provinces of meaning thus offer these time-outs from the world of everyday life. In everyday life, the acting individual constantly has to make decisions about how they should proceed, and some of these are indeed very consequential. For Garfinkel, this is a "practical question par excellence: 'What to do next?'" (1967: 12). This pressure of decision-making and acting is absent in the realities of closed provinces of meaning: within them, the burden of everyday actions is taken off us.

\section{Resources and Competences}

The question of access is not always settled as democratically as in the case of sleeping and dreaming (but in the end: anyone can go insane). Some provinces of meaning have elitist structures. Regular frequentation of closed provinces of meaning can indeed be a luxury and count among the privileges of certain individuals or certain social classes. Access to the various provinces of meaning is dependent on resources and competences, and thus linked to the social structure of the world of everyday life. This is true not only of luxurious provinces requiring costly resources. Social structure plays a significant role for the availability of a variety of provinces of meaning. Consider the obvious example of fictional worlds. While anyone can enter into a state of daydreaming and access to fictional worlds is not initially dependent on resources, literary provinces of meaning require specific cultural competences-particular reading techniques-in order to be accessed. Schutz' own example taken from Cervantes' novel and Don Quixote fighting windmills is one case in point (1964a). The province of meaning of art is dependent on socially derived competences and artifacts passed on through the ages. Some have to be struggled for with great effort (e.g., playing the piano, reading sheet music) or require the use of material resources (e.g., admission or tuition fees). In accessing the provinces of meaning of art and science, artistic expertise and stocks of knowledge play a major part. As is known, this knowledge is socially derived and stocks of knowledge are subject to social distribution (Schutz and Luckmann 1973: 243-331). What can be said, then, is that the social stock of knowledge plays a part in accessing finite provinces of meaning. In order for specific finite provinces of meaning to be accessed, specific stocks of knowledge must be available (e.g., reading sheet music) and the skill of handling artifacts must be learned (e.g., a musical instrument). These competences can only be obtained in the world of everyday life, and they are usually shared intersubjectively by a trainer or a master. Even at a stage as early as entry tests or initiation rites, access to the artistic expertise of finite provinces of meaning can be highly restricted. 


\section{Sociality and Communication}

The world which unfolds itself in making music together, described elsewhere by Schutz (1964b), reveals a further aspect concerning the properties of finite provinces of meaning: the question of the specific sociality. While I may dream of others, the dreaming can only be done by myself. When asleep, I am not accessible to others (although they may observe me in my sleep). The sleeping ego does not engage in communication with either a waking or a sleeping alter ego. By contrast, there are other finite provinces of meaning, which are dependent on interaction and a specific form of sociality. The worlds of art and sleep may be available to the lonesome ego, but making music together requires interaction with others in order for the subworld to be generated and sustained. Existence and attainment of this shared province of meaning is conditional on the coordination between the musicians in the world of everyday life as well as in the sub-world itself. It is obvious, then, that constitution of these provinces of meaning is necessarily of a social nature and requires interaction. Schutz already pointed out that intersubjective sharing of finite provinces of meaning is possible. While it is true that intersubjectivity is an essential property of the world of everyday life, it does not follow that other provinces of meaning cannot be shared intersubjectively:

To be sure, there are certainly finite provinces of meaning which cannot be intersubjectively shared, such as my dreams or even my daydreams. There are others, such as the play world of children, which permit intersubjective participation and even interaction in terms of the shared fantasms. In the world of religious experiences there is, on the one hand, the lonely vision of the mystic or of the prophet and, on the other hand, the community service-there are lonely prayers and prayers offered by the congregation. (1962c: 342)

This is true, however, also of playing games in a broader sense, i.e., a game of tennis, table games, board games, and computer games; all of these require interaction and communication with respect to this province of meaning with its own rules and often even its own language. The sub-worlds of playing games and making music (together) have precise and sometimes explicitly stated rules of interaction (e.g., rule books or actual 'playing instructions'); most importantly, however, they are subject to clearly defined rules of reciprocity which must be followed or otherwise the specific meaning of the sub-world is jeopardized to the extent of causing a crisis of the province of meaning and a conflict in the world of everyday life. (Recall Garfinkel's crisis experiments, e.g., the experiment on rule violations in playing tic-tac-toe and their most life-worldly consequences of arguments and accusations; 1963.)

\section{Transitions and Connections}

What remains relatively open in Schutz is the question of the transitions and connections between the various provinces of meaning and the world of everyday life. What consequences do the finite provinces of meaning have for the being in the state of wide-awakeness? In what way do they perhaps contaminate the 'here' and 'now' of wide-awakeness? In one place (1962a: 233, fn 19) Schutz speaks of 
"enclaves," which may be formed by finite provinces of meaning within the world of everyday life (but also within other provinces): "There is, furthermore, the problem of 'enclaves,' that is, of regions belonging to one province of meaning enclosed by another (...)". Through their spatial metaphors, the terms used by Schutz-"provinces," "leap," the concept of a spatial border contained in "finite"-suggest that the conception is one of cohesive and clearly separated and delineated regions. And yet this is not Schutz' intent at all; instead, he emphasizes the gradual and regular nature of the transitions:

As we have said before, my mind may pass during one single day or even hour through the whole gamut of tensions of consciousness, now living in working acts, now passing through a daydream, now plunging into the pictorial world of a painting, now indulging in theoretical contemplation. All these different experiences are experiences within my inner time; they belong to my stream of consciousness; they can be remembered and reproduced. (1962a: 258)

These provinces of meaning are thus recurring and ubiquitous parts of the lifeworld. Their presence in the world of everyday life and the transitions between them have effected the formation of routines. For instance, we may specifically seek out places in order to enter the respective finite provinces of meaning (a theater, a house of prayer). In some cases, we are bound by special times (the show, the service). It thus becomes apparent that the temporal and spatial layering, to which Schutz attributes such a significant role (which the mere outline of Structures of the LifeWorld indicates), is of some consequences also for the embedment and the entryways to the provinces of meaning.

The various realities do not allow communication from one to the other. Their cognitive styles are not transferable between them (Schutz and Luckmann 1989: 144). This is an argument which Schutz expounds in more detail primarily in "Symbol, Reality and Society". Language as a means of communication is founded in the world of everyday life. When speaking about experiences from finite provinces of meaning (about theater or art), we do so in the world of everyday life and consequently make use of the means of communication which dwells and is based in the world of everyday life.

In other words, communication can occur only within the reality of the outer world, and this is one of the main reasons why this world, as we will see very soon, has the character of paramount reality. Even the voices which the schizophrenic believes he hears are hallucinated as voices, and refer, therefore, to events within the outer world. (1962c: 322)

As a means of communication of the world of everyday life par excellence, language only to some extent suits the purpose of expressing or conveying experiences from finite provinces of meaning (as is known to anyone trying to recount a dream). Experiences gone through in a dream, religious episodes, or for instance an epileptic seizure prove to be difficult to convey in everyday communication, and attempts at describing them frequently fail.

However, language is not necessarily a boundary for the passage between provinces of meaning (for an extensive discussion of this problem see Sebald 2011). Language and other semiotic systems equally serve as means of generating finite 
provinces of meaning such as theater, literature, or art. For religion, too, language plays an important role (both for the ritualistic practices and generally: religion produces 'holy' scriptures). Finally, there are professions in the world of everyday life specifically devoted to finite provinces of meaning (dream interpreters, psychoanalysts, or science and art professionals). Strictly speaking, making dreams the subject of science or art represents a finite province of meaning within a finite province of meaning (i.e., an enclave in Schutz' sense).

\section{The Boundaries of Worlds and Their Inhabitants}

Finite provinces of meaning possess their own internal structures, giving them their particular nature and allowing them to be separated and distinguished from one another. The structures of the various realities, however, are determined to a large extent also by how they are inhabited and who is taken to be a legitimate inhabitant. In the world of games, I tend to play with other players who like me have entered this sub-world. Just like me, they will return into the world of everyday life once the game has finished. There, I can encounter them as everyday individuals and for instance make an appointment with them to play a game. By contrast, the special social world of dreaming as a finite province of meaning may be populated by people whom I cannot encounter in a flesh-and-blood form, e.g., because they are my predecessors or because they are creatures who only exist in the world of dreaming. As for the world of fancy, the 'personnel' of the finite province of meaning is remarkably diverse. It may consist of witches, elves, moomins, dragons, orcs, winged horses, speaking ravens, and many other creatures, with whom I may also be familiar as individual characters, such as Oberon, the Elf King, or Shakespeare's Puck. Moreover, familiar objects from the world of everyday life may there have a completely different meaning (a broom); things which do not exist in my world of everyday life may there play a central role (the fur of a golden ram who can not only fly but also speak). Finite provinces of meaning possess their own social worlds and their own structures of plausibility. What may be seen as a plausible contemporary in one world could be out of place in another. Who or what can be considered a legitimate or plausible inhabitant of a sub-world, as the examples demonstrate, is a result of conventions. Finite provinces of meaning are governed by their own laws: its inhabitants by no means have to be humans.

At the same time, we may observe that also the realities of the everyday lifeworld are by no means homogeneous. As Endress (2003) demonstrates, the lifeworld is not only divided in multiple realities, but also contains social modifications. The reality of an individual's own group is indeed experienced as self-evident; and yet it faces the "plurality of everyday realities" of groups of others (2003: 105; our translation). The world of everyday life is thus not a homogeneous terrain to roam in-it is interspersed both with familiarity and unfamiliarity. To be sure, the world of everyday life is certainly familiar, but "within this familiarity, unfamiliarity itself is a familiar phenomenon" (2003: 113; our translation).

The life-world familiar to others may be unfamiliar to me. What to others may seem part of their everyday reality may seem 'alien' to me. As Luckmann (1970) demonstrates, it is also true of the world of everyday life and its natural attitude of 
wide-awakeness that the equation of the social world with the human world is by no means generally applicable. As an example, Luckmann (1970) mentions cultures which adhere to totemism. By appeal to Reo Fortune's ethnography of the Dobu, a people inhabiting the D'Entrecasteaux Islands, Papua New Guinea, West Pacific, he shows how the "boundaries of the social world" may be drawn. For the Dobu, yam plants are part of the social world. They are conceived of as humans equipped with the capacities of moving (they walk around at night and return to the garden in the morning) and speech (Fortune 1963: 107-109). The Dobu themselves show their consideration by avoiding the gardens at night and refrain from doing garden work in the morning ("We wait till the sun has mounted. Then we know they are back" Fortune 1963: 108). The argument Luckmann draws from this aims to show that "the coincidence of the social and the human which is evident to us is by no means universally perceived" (1970: 73). With reference to analyses of totemist cultures, Luckmann writes: "It became clear that the identification of the social with the human could not be considered universal and that the neat separation between nature and society had not been evident to all men in all times" (1970: 81).

The boundaries, that is, between the actors of the world of everyday life and the sub-world are not necessarily drawn along the distinction between human and non-human inhabitants. For the Dobu, yam plants are part of the reality of everyday life. In the Western world, however, such elements are generally excluded from the world of everyday life and accommodated in the finite provinces of meaning - fancy, religion-as a result of which yam plants (at least as long as they are walking and talking), elves, trolls (and, luckily, Puck) are not part of the everyday world. This expulsion of non-human inhabitants from the world of everyday life is not without consequences. Luckmann speaks of a "desocialization of the universe" (1970: 86-96). The respective phenomena are dispatched to other worlds: "There is a close connection between the desocialization of the world and the articulation of a religious symbolic universe" (Luckmann 1970: 95).

The finite provinces of meaning themselves make anthropological universals. They are known to every ethnicity and culture. However, the composition of their internal structure, their entryways, their boundaries, and their inhabitants result from historical processes and social attributions. No other finite province of meaning demonstrates this as clearly as religion.

\section{Life-World, After-Worlds, and Ultimate Provinces of Meaning}

Schutz explicitly counts religion among the finite provinces of meaning, although he mentions religion more in passing or when listing different provinces of meaning. ${ }^{2}$ Religion, quite unlike dreaming, fancy, and theoretical contemplation, is not one of

\footnotetext{
${ }^{2}$ In the text on multiple realities, religion is mentioned only en passant as "the religious experiences in all their varieties" and "the leap into the religious sphere" (1962a: 231), as "the world of religious experience" (1962a: 232); furthermore "religious meditation" (1962a: 245) and "religious symbols" (1962a: 258).
} 
the provinces of meaning to which Schutz devotes any in-depth consideration in "On Multiple Realities". His primary concern is not with religion, but with science as a finite province of meaning. At the beginning of his text, he thus writes, "[t]he following considerations, fragmentary as they are, attempt to outline a first approach to some of them with the special aim of clarifying the relationship between the reality of the world of daily life and that of theoretical, scientific contemplation" (1962a: 208). In strict accordance with this agenda, he does not include a definition of religion. This is exactly the void which the following considerations are meant to fill. Focusing on religion as a finite province of meaning, they will attempt to provide a more detailed description of the features of this province of meaning. The conception of religion used in this analysis is a 'broad' (functional) one, going back to Luckmann $(1967,1985,1991 \mathrm{a}, \mathrm{b})$ and covering transcendental experience of noneveryday realities. "[...] I apply the term religious to those layers of social constructions of reality which spring from transcendental experiences and are comprehended, more or less insistently, as referring to a non-everyday reality" (1985: 35; our translation). The main criticism against this conception of religion is well known (see Dobbelaere/Lauwers 1973). It is accused of being too broad and too unspecific to capture specific religious experiences. However, it is precisely its reference to the notion of transcendence that makes it well-suited to the purposes of this essay.

\section{Religion as a Finite Province of Meaning}

At an initial stage, religion as a finite province of meaning, just as other subuniverses, features a special cognitive style (consisting of a particular tension of consciousness, a particular form of sociality, a particular temporal perspective, etc.; see Schutz 1962a: 232f.). What exactly do these different features of the finite province of meaning of religion look like?

The finite province of meaning of religion is among those that can be "intersubjectively shared" (see Schutz 1962c; 1962a: 232f.). In fact, there is an urge toward communalization. There are other provinces of meaning which generate communities (the world of games for example), and yet this is not true of all of them. There is no community of sleepers, dreamers, and (supposedly) no community of insane people. The communalization of those practicing religion is achieved through religious practices required for the generation of these communities, such as religious services or the performance of rituals. Hence, religious practices are a product of existing communities of adherents, but at the same time continually re-constitute them. To be sure, there are other religious practices which may be carried out also in solitude (meditation, prayer, fasting, etc.), and in many religions, there exist such figures as the hermit or the ascetic saint choosing a life of seclusion. Unlike many other provinces of meaning, that of religion can be entered both alone and in company. The reason this double gateway is of such great importance for the linkup of religion as a finite province of meaning to the world of everyday life is that it allows this-worldly communion without making it a prerequisite for religious experience. 
Communalization and religious practices, however, may themselves form the basis of an entrance to a finite province of meaning. By way of religious practices like intensive fasting or meditation, finite provinces of meaning may be generated and access to them may be allowed. The finite province of meaning of religion is not simply entered, it is generated from within the world of everyday life by these particular practices. Communally performed practices play such a salient role in it that we may speak of a social construction of religion as a finite province of meaning whose interior space of experience is socialized.

Questions of access, however, also help to show the extent to which the finite province of meaning of religion is heterogeneous. Aside from religious practices, a number of 'states' may be identified among the experiences of religious provinces of meaning which do not take place within communities and about which those affected often report that the experience renders them powerless, occurring independently of their intentions. This includes conversion experiences, entrancement, crises of all types, rapture, transcendental or near-death experiences, and of course any form of mysticism.

It seems obvious that for religious provinces of meaning, enclaves play a significant role. Schutz uses this term to designate finite provinces of meaning which are enclosed by others. In the special case of religion, dreams are a wellknown example of such an enclave. Sources as old as the Gilgamesh epic include descriptions of dream sequences; 'dream books' are known from Ancient Egypt; and the most famous examples from the Old Testament is Jacob's dream of the celestial stairs (in the New Testament Joseph dreams of an angel urging him to flee to Egypt). Enclaves are enclosures of finite provinces of meaning in other finite provinces of meaning. Furthermore, migration from one finite province of meaning into another is possible and presumably not a rare phenomenon. While in many religions, non-everyday experience manifests itself as non-everyday perception ("apparitions"), the credibility of those having such experiences is continually questioned by their environment and attributed to another finite province of meaning - that of insanity. This is exemplified by the "Jerusalem Syndrome," a hallucination found in Jerusalem, in which patients think they are figures from the New or Old Testament, which is mostly diagnosed as a mental illness. Joan of Arc, who among other things heard the voice of Michael the archangel, was accused of heresy. It thus becomes clear that experiences of finite provinces of meaning are not without danger and may have perilous consequences in the world of everyday life.

Provinces of meaning possess (aside from the phenomenon of enclaves) the striking feature that they generate what may be called gateways, i.e., connecting parts between finite provinces of meaning and the world of everyday life. In "Symbol, Reality and Society" (1962c), Schutz granted symbols a central role for the connections between finite provinces of meaning: symbols are "appresentational references of a higher order" (1962c: 331). Unlike indications, marks, and signs,all of which are of a 'this-worldly' nature-symbols are references which point beyond the everyday and which transcend everyday experience. Symbols connect finite provinces of meaning to the world of everyday life: The appresentational object-the "appresenting symbol"-is a constituent part of the world of everyday life (Schutz 1962c: 343), and it is in this capacity that the symbol points to finite 
provinces of meaning. Schutz and Luckmann speak of "boundary crossings" (1989: 131). It is indeed also common for indications, marks, and signs to point to something not present and thus to cross boundaries. But the target of a symbol is another finite province of meaning. Schutz and Luckmann use the term "bridge" to point out the boundary-crossing power of symbols: "[...] they throw a bridge from one province of reality to the other (...)" (1989: 144). Symbols can take a variety of forms. Schutz explicitly names "expressive, purposive, or mimetic gestures, linguistic or pictorial presentations, charms, spells, magical or religious rites, ceremonies" (Schutz 1962c: 335f.). Many of these symbol carriers are mobile and require no or only few material aids. References to other realities are thus an almost ubiquitous part of the world of everyday life - the everyday is indeed pervaded by them. Schutz uses the example of the Jacob's Ladder to illustrate that virtually any object of everyday life may become a reference to a higher order and experience of the transcendental is possible virtually anywhere. Schutz speaks of "the irruption of the transcendent experience into the world of everyday life, which transforms it and gives each element of it an appresentational significance" (1962c: 337f.). And yet, we cannot help but notice that the distribution of symbols is not an arbitrary one. Religion, above all, makes sure that these symbols have a stubborn dependence on times and places.

Religions generate gateways of a spatially and temporally finite nature within the world of everyday life: in houses of prayer, which provide fixed places of worship where the community assembles, in calendars of feast days requiring the assembly of the adherents at fixed and recurring times of the year (defined in the liturgical year in Christianity). These gateways allow access to the finite provinces of meaning, serving in fact as a type of portal to a different reality. Gateways indeed possess their own character and their own force of working upon their inhabitants and visitors. A cloister garden is capable of (and indeed intended to) help its visitors attain a contemplative state of mind and turn inward; it is hardly possible not to be seized by the Chartres Cathedral; etc. Durkheim had already described the isolation of the holy places and times from the world of everyday life as "elementary forms of religious life". In particular, it is the purpose of the so-called negative rites to achieve separation of the sacred from the profane (Durkheim 1971: 299-325). According to Durkheim, it is a key characteristic of religion that it creates sacred times and places. "By definition, sacred beings are separated beings" (1971: 299). These gateways can be specifically frequented in order to gain or facilitate access to another reality - a cathedral, a cloister garden, etc.

Not only religions are in possession of these fixed-installed gateways between everyday reality and the closed province of meaning. For players, game conventions may play the role of a gateway; for fans of rock music it may be festivals, and so forth. Just as a cloister garden can serve as the portal to a finite province meaning, the San Diego Comic-Con or the Glastonbury Festival are established spaces of passage into other provinces. Gateways thus create transitions between finite provinces of meaning and at the same time domesticate them. At an initial stage, religions generate detachment from the world manifested on the one hand in the above-mentioned life choices of hermiticism and asceticism. But the gateways do 
not necessarily entail complete abandonment of the world on the part of their inhabitants.

This raises the question of institutionalization of such locations and events. Endress notes that the handling of various forms of transcendence is organized and controlled by society (2003: 108). At the initial stage, closed provinces of meaning are an individual's inner experiences. However, institutionalization and social control of its entryways-'holy' places, 'holy' times-generate social structures and material facts within the everyday life-world which in turn shape and channel the accesses to various closed provinces of meaning. People seeking out such places have expectations of them which, as with any kind of expectation, they may live up to or fall short of.

It is especially these passageways to the closed province of meaning of religion which show how much they are subject to historical and socio-structural change. Thomas Luckmann's theses of the individualization and privatization of religion aim to show that this offer of religious provinces of meaning and gateways is historically diverse. In the afterword to the German 1991 edition of The Invisible Religion (Die unsichtbare Religion), he writes:

The specifically religious constructions of experience [...] in Western societies were once placed under the monopoly-like control (canonization, censorship) of the Christian Church. In the meantime, the traditional Christian, specific religious representations are by no means the only ones found on the 'market' of 'sacred universes.' Instead, they must compete with religious orientations (...) of various origin. (1991a: 180; our translation)

Luckmann refers to this competition of orientations and religious offers of meaning as a "commodity market of transcendencies" (1991a: 180). It is composed, Luckmann explains, of (explicitly) religious representations taken from other religions, but also of distinctly secular everyday models. Luckmann's argument also applies to the finite provinces of meaning. The "commodity market" characterization is also true of practices through which finite provinces of meaning may be attained without necessarily involving any religious creeds, e.g., breathing or drumming courses, practices of meditation or yoga, etc. The "commodity market of transcendencies" described by Luckmann leads not only to a possibility of choice, but also to established symbols and gateways losing their realities-crossing potential. A cloister garden, for instance, can suffer the fate of not being perceived as a religious place, but simply as a shady and beautiful spot.

\section{The Life-World and the After-Worlds}

The spatial and temporal structuring found in religious provinces of meaning and worldly gateways extends into models of non-secular worlds in visions of a hereafter and paradises. These visions consist of spatio-temporal imaginings of (other) worlds, taking (from the perspective of the everyday human) their place in the past or future, not existing parallel to the world of everyday life. Unlike finite provinces of meaning, notions of paradises and hereafters do not provide the possibility of coming back to the world of everyday life-they are places of no 
return. Through notions of hereafters, religions effect an irreversible separation of this world and the transcendent world. Nor are conceptions of hereafters one province among many; they are ultimate provinces of meaning.

The exact spatial and temporal positioning of hereafters and paradises differs from religion to religion. The Garden of Eden envisioned in the Old Testament and described in Gen 2:10-14 has been targeted with many attempts to localize it, and the narrative does indeed make references to locations (mentioning "the east" as well as the rivers Euphrates and Tigris). In the Ancient Egyptian culture, the realm of the dead is located, on the one hand, in the west (the place of the setting sun where the sun god Re seeks shelter with Osiris) and on the other hand in the underworld (through which Osiris safely guides Re). According to the myth adhered to on the Trobriand Islands (South-West Pacific), the ghosts of the dead inhabit the island of Tuma, which is located not too far from the island of the living, allowing the dead to pay regular visits to the living (Malinowski 1954: 155). Paradises may be future worlds which the respective religion promises to be attained on specific conditions. These conditions, however, must be satisfied in this world (e.g., the paradises which Islam holds in store for its adherents). Likewise, paradises may be worlds of the past to which access has been lost by man (the Garden of Eden, the paradise of the book of Genesis, is an example).

It becomes apparent, then, that many religions set against the fugacity of this lifeworld a hereafter canceling the temporal restrictedness of human life. The idealizations of "I can do it again" and "and so on," valid in the world of everyday life, are not idealizations in that world, with the spatial and temporal structuring losing its significance. Most importantly however, paradises are liberated, so to speak, of the "world of working" of everyday life. Alois Hahn, in Sociology of Paradise Conceptions (Soziologie der Paradiesvorstellungen), points out that the conception of paradise as a garden (e.g., in Christianity and Islam) presents itself as the "earthly bliss of a simple agricultural society" (1976: 11; our translation). Initially that is, there is a resemblance between paradise conceptions and earthly life. "The hereafter invariably retains features of the respective secularity," as Hahn writes (1976: 23). However, the two differ in crucial respects: There is no famine and no toil. "Paradise, as it were, is a repetition of the everyday dasein without its laborious painful circumstances" (Hahn 1976: 11). Hereafter conceptions therefore never fail to be remarkably concrete and detailed. For Hahn, these similarities between paradises and the world of everyday life demonstrate that "paradise conceptions are socially conditioned" (1976: 11). In many cases, paradise and hereafter conceptions feature fantastic elements. What distinguishes them from fantasizing, however, is the essential fact that in the case of the latter, he who engages in it is aware that he is in a world of fancy, while the religious believer by no means takes his hereafter conception to be a province of meaning or a figment of their imagination. Moreover, fantasizing individuals, in a completely different way, are in control of their ideas. "The imagining individual masters his chances: he can fill the empty anticipations of his imageries with any content he pleases; as to the anticipating of imagined future events he has freedom of discretion" (Schutz 1962a: 238f.). From such freedoms and choices, aspirants for the hereafter are far removed. Access and processes of admission are subject to explicit representations. Some 
hereafters have wardens guarding the entrance. In Greek mythology the entrance to the underworld is guarded by Cerberus, ensuring that no living person enters and no dead exits. For the Trobriand Islanders studied by Malinowski, the deceased are awaited by Topileta, ruler of the villages of the dead (1954: 156). Some of these worlds can only be attained by heroes and martyrs (Elysium, Valhalla), but surely not anyone. Many hereafters, it seems, are thus elitist. Entering them therefore is indeed similar to passage rites in Van Gennep's sense (1960), with the exception that the aspirant's concern is nothing less than admission to the ultimate province of meaning. Many religions know the idea of a judge or a court of the dead issuing a verdict on the admission of individual aspirants based on their deeds in life (i.e., in the world of daily life). In Ancient Egypt, for example, a judge whose verdict one could previously not be sure of had to be convinced. The impact of these conceptions, especially in Ancient Egypt, are more than remarkable. This is because the requirements of the court of the dead do not take the form of merits which as in an entry test could be accomplished in situ. Instead, the judgment looks at the deeds done in life, and thus at this world and the actions of the world of everyday life. The prospect of having to stand trial before a judge after death does indeed make an impression on the living. It also determines the world of the living and pervades everyday action. In Ancient Egypt, these notions influence everyday life; they have an effect on art and-still visible millenniums later-on architecture (Assmann 2005). Notions of the trials and the dangers of the hereafter are so explicit that in the world of everyday life, a strand of literature specifically concerned with them has emerged-the so-called "books of the dead". These contain explicit advice on how to approach the dangers after death and are given to the dead for their passage. The hereafter is not always a safe place.

Unlike the finite provinces of meaning described by Schutz, these religious conceptions of hereafters and paradises (the ultimate provinces of meaning) transcend the here and now of the world of everyday life. Often enough they also contain notions of the beginning and the end of the cosmos. For instance, creation myths describe how the world, which is home (also) to the world of everyday life, first came into existence. Occasionally, there are apocalyptic conceptions of the end of all time and the beginning of a completely new eon, overcoming this world once and for all and thus leaving behind the world of everyday life ("a new heaven and a new earth," Rev 21:1).

\section{The Sub-Universes and Everyday Reality}

The three-fold correlation between the world of everyday life, the religious finite provinces of meaning, and finally the conceptions of hereafters and paradises is by no means unambiguous. In the different religions, the three worlds enter wholly different relationships with each other. On the one hand, conditions faced in the hereafter may be influenced by practices in this world, the world of everyday life. Expecting after-death judgment of the deeds done in life, any believer will be anxious to live their life in this world according to the particular religious expectations. Already in Ancient Egypt, Ma'at, i.e., proper conduct of life, played an important role for daily life and the behavior toward the gods. Breasted (1934) 
dates the "dawn of conscience" at this time. In the famous "Teaching for Merikere" a father gives an urgent warning to his son (end of the 22nd century BC):

The court of judges who judge the unworthy, thou knowest that they are not lenient on that day of judging the wretched, in the hour of executing the writ.

... Set not thy mind on length of days, for they (the judges) view a lifetime as an hour. A man surviveth after death and his deeds are placed beside him like mountains. For it is eternity, abiding yonder (in the next world), and a fool is he who disregards it. (Breasted 1934: 157)

Other religions develop catalogs of behavior (e.g., a "Decalogue" carved in stone) for the proper behavior toward contemporaries, predecessors, and the respective deities. They attach great importance to participation in religious practices (invocations, praise, meditation, prayer, etc.). In the Hindu teaching of reincarnation, the threat is less non-admittance to the hereafter than re-birth as a lesser being ("As one acts and conducts oneself, thus one becomes"). Buddhism attempts to escape this circle of death and re-birth ("Samsara") by non-attachment to the earthly. Nirvana, the state of being "blown out," may be attained, for example, by asceticism and meditation, even allowing the option of inner-worldly redemption.

The hereafter, the finite provinces of meaning, and the world of everyday life interlock in the most diverse ways and influence each other. This relationship has repeatedly been subject to studies in the sociology of religion. Perhaps the most prominent example of the relationship between hereafter conceptions and finite provinces of meaning and the world of everyday life can be found in Weber's (2005) description of the beliefs of the Calvinist doctrine of predestination. According to this teaching, it is irrevocably certain who of the living is, and who is not among the chosen. The anxiety and uncertainty of the individual adherents with respect to their chances of attaining bliss in that world leads to restless labor and ascetic conduct of life in this world. It is only by the success achieved in this labor that the individual may guess whether they may not after all indeed be among the doomed ones-only guess; for certainty of it cannot be obtained because the Calvinist god remains silent on the matter, leaving the adherents in permanent doubt. As Weber describes, this gives rise to "a feeling of unprecedented inner loneliness of the single individual" (2005: 60). The example of Calvinism shows the extent to which conceptions of the hereafter (can) impact this world and the enormous consequences they have: for the individual that becomes lonely as well as for the society as a whole that changes its countenance and brings forth "modern economic man" (moderner Wirtschaftsmensch) (Weber 2005: 117). What, ultimately, also undergoes a change is the correlation between a finite province of meaning and the everyday. Previously monkish asceticism becomes part of everyday life-“worldly asceticism" (innerweltliche Askese) (Weber 2005: 97) arises. It is the hereafter conceptions of Calvinism through which an attitude is exported from the finite provinces of meaning (monkish asceticism) into the world of everyday life (as worldly asceticism), thus bringing about permanent change in it. 


\section{Conclusion}

The considerations provided have shown that the life-world is a complex matter breaking down into various parts. The world of everyday life with its state of wideawakeness, its special accent of reality, and the predominant pragmatic motive is but a part of it. At the same time as this world of everyday life, there exist finite provinces of meaning accessible to individuals to various degrees and governed by a different accent of reality. All of these taken together constitute the "multiple realities". They differ essentially in the role fundamental anxiety plays within them.

For Alfred Schutz, fundamental anxiety is of central relevance for the everyday world. It determines the basic experience of the natural attitude. In Schutz' view, it is fundamental anxiety that gives rise to everything else: "From the fundamental anxiety spring the many interrelated systems of hopes and fears, of wants and satisfactions, of chances and risks which incite man with the natural attitude to attempt the mastery of the world, to overcome obstacles, to draft projects, and to realize them" (1962a: 228). In his notebooks for The Structures of the Life-World, he refers to fundamental anxiety as the "supreme motive of the relevance system" (Schutz and Luckmann 1989: 307).

In hereafter conceptions, which here have been studied as "ultimate provinces of meaning," fundamental anxiety is placed in the center. These conceptions explicitly address the question of what will become of the individual once they depart from the world of the living, the life-world. Subscribing to Peter Berger's view that "[r]eligion is the human enterprise by which a sacred cosmos is established" (1967: 25), it becomes apparent that ultimate provinces of meaning are a part of this enterprise. Hereafter conceptions are projections referring to man's fate after death. The "sacred canopy" (Berger) encompasses this world and that world and thus also includes the finite provinces of meaning. Fundamental anxiety thus not only proves to be a determining element of the systems of relevance in the natural attitude. It is also responsible for the emergence of hereafter conceptions transcending the boundaries of human existence. Hence, fundamental anxiety is the basis for this world and for the conceptions of that world.

By the same token, the provinces of meaning also correlate with it, making possible the retreats from the world of everyday life and the fundamental anxiety by which it is determined. The finite provinces of meaning, as diverse as they are, provide time-outs from the world of everyday life which man obviously takes to be worthwhile and experiences as a relief. Fundamental anxiety, therefore, is the motor of all realities: the relevancies of everyday life in this world, the small and large escapes available through provinces of meaning. For what is absent from or at least strongly reduced in finite provinces of meaning is the fundamental anxiety that is the fear and the knowledge of the finiteness of life.

Acknowledgments Open access funding provided by University of Klagenfurt. I am indebted to Ruben Bieker, Paris, for his accurate translation of this text. I owe many thanks to two anonymous reviewers for their helpful suggestions. 
Open Access This article is distributed under the terms of the Creative Commons Attribution 4.0 International License (http://creativecommons.org/licenses/by/4.0/), which permits unrestricted use, distribution, and reproduction in any medium, provided you give appropriate credit to the original author(s) and the source, provide a link to the Creative Commons license, and indicate if changes were made.

\section{References}

Assmann, J. (2005). Death and salvation in ancient Egypt. Ithaca, NY: Cornell University Press.

Berger, P. L. (1967). The sacred canopy. Elements of a sociological theory of religion. New York: Doubleday.

Berger, P. L. (1970). The problem of multiple realities: Alfred Schutz and Robert Musil. In M. Natanson (Ed.), Phenomenology and social reality. Essays in memory of Alfred Schutz (pp. 213-233). The Hague: Nijhoff.

Biemel, W. (1983). Zur Realitätsträchtigkeit des Irrealen. In R. Grathoff \& B. Waldenfels (Eds.), Sozialität und Intersubjektivität. Phänomenologische Perspektiven der Sozialwissenschaften im Umkreis von Aron Gurwitsch und Alfred Schütz. (pp. 252-271). München: Wilhelm Fink.

Breasted, J. H. (1934). The dawn of conscience. New York: Scribner.

Chojnacki, M. (2012). "Secularization” or plurality of meaning structures? A. Schutz's concept of a finite province of meaning and the question of religious rationality. Open Journal of Philosophy, 2(2), 92-99.

Dobbelaere, K., \& Lauwers, J. (1973). Definition of religion. A sociological critique. Social Compass, 20(4), 535-551.

Dreher, J. (2003). The symbol and the theory of the life-world: "The transcendences of the life-world and their overcoming by signs and symbols". Human Studies, 26(2), 141-163.

Durkheim, E. (1971). The elementary forms of the religious life. London: Allen \& Unwin.

Endress, M. (1998). Alfred Schutz's interpretation of Cervantes's Don Quixote and his microsociological view of literature. In L. Embree (Ed.), Alfred Schutz's "sociological aspect of literature": Construction and complementary essays (pp. 113-128). Dordrecht: Kluwer Academic Publishers.

Endress, M. (2003). Die Einheit multipler Sinnordnungen in der sozialen Welt. In M. Kaufmann (Ed.), Wahn und Wirklichkeit-Multiple Realitäten. Der Streit um ein Fundament der Erkenntnis (pp. 99-118). Frankfurt am Main: Peter Lang.

Endress, M. (2014). "The man without qualities" and the problem of multiple realities: Alfred Schutz and Robert Musil revisited. In M. Barber \& J. Dreher (Eds.), The interrelation of phenomenology, social sciences and the arts (pp. 157-172). Dordrecht: Springer.

Flaherty, M. G. (1987). Multiple realities and the experience of duration. The Sociological Quarterly, 28(3), 313-326.

Fortune, R. F. (1963). Sorcerers of Dobu. The social anthropology of the Dobu Islanders of the Western Pacific. London: Routledge \& Kegan Paul.

Garfinkel, H. (1963). A conception of, and experiments with, "trust" as a condition of stable concerted actions. In O. J. Harvey (Ed.), Motivation and social interaction: Cognitive approaches (pp. 187-238). New York: Ronald Press.

Garfinkel, H. (1967). Studies in ethnomethodology. Englewood Cliffs, NJ: Prentice-Hall.

Goffman, E. (1974). Frame analysis. An essay on the organization of experience. New York: Harper \& Row.

Grathoff, R. (Ed.). (1989). Philosophers in exile: The correspondence of Alfred Schutz and Aron Gurwitsch, 1939-1959. Bloomington, IN: Indiana University Press.

Gurwitsch, A. (1964). The field of consciousness. Pittsburgh, PA: Dusquesne University Press.

Hahn, A. (1976). Soziologie der Paradiesvorstellungen. Trier: NCO-Verlag.

Hermida-Lazcano, P. (1996). The taken-for-granted world: A study of the relationship between A. Schutz and J. Ortega y Gasset. Human Studies, 19(1), 43-96.

Husserl, E. (1969). Formal and Transcendental Logic (D. Cairns, Trans.). The Hague: Nijhoff.

James, W. (1890). The principles of psychology (Vol. 2). London: Macmillan.

Kassab, E. S. (1991). "Paramount reality" in Schutz and Gurwitsch. Human Studies, 14(2/3), 181-198. 
Kersten, F. (1998). Some reflections on the ground for comparison of multiple realities. In L. Embree (Ed.), Alfred Schutz's "sociological aspect of literature”: Construction and complementary essays (pp. 149-168). Dordrecht: Kluwer Academic Publishers.

Knoblauch, H. (1998). Transzendenzerfahrung und symbolische Kommunikation. In H. Tyrell, V. Krech, \& H. Knoblauch (Eds.), Religion als Kommunikation (pp. 147-186). Würzburg: Ergon.

Luckmann, T. (1967). The invisible religion. London: Macmillan.

Luckmann, T. (1970). On the boundaries of the social world. In M. Natanson (Ed.), Phenomenology and social reality. Essays in memory of Alfred Schutz (pp. 73-100). The Hague: Nijhoff.

Luckmann, T. (1985). Über die Funktion der Religion. In P. Koslowski (Ed.), Die religiöse Dimension der Gesellschaft. Religion und ihre Theorien (pp. 26-41). Tübingen: Mohr.

Luckmann, T. (1991a). Die unsichtbare Religion. Frankfurt am Main: Suhrkamp.

Luckmann, T. (1991b). The new and the old in religion. In P. Bourdieu \& J. S. Coleman (Eds.), Social theory for a changing society (pp. 167-182). Boulder, CO: Westview Press.

Malinowski, B. (Ed.). (1954). Baloma. The spirits of the dead in the Trobriand Islands. In Magic, science and religion and other essays (pp. 149-274). Garden City, NY: Doubleday Anchor Books.

Marx, W. (1970). The life-world and the particular sub-worlds. In M. Natanson (Ed.), Phenomenology and social reality. Essays in memory of Alfred Schutz (pp. 62-72). The Hague: Nijhoff.

Nasu, H. (1999). Alfred Schutz's conception of multiple realities sociologically interpreted. In L. Embree (Ed.), Schutzian social science (pp. 69-85). Dordrecht: Kluwer Academic Publishers.

Nieder, L. (2006). Lebenswelt, Alltagswelt, die Vielfalt der Wirklichkeiten und die Sinnprovinzen der religiösen Erfahrungen in der phänomenologischen Soziologie von Alfred Schütz. In M. Drewsen \& M. Fischer (Eds.), Die Gegenwart des Gegenwärtigen. Festschrift für P. Gerd Haeffner SJ zum 65. Geburtstag (pp. 270-281). Freiburg: Karl Alber.

Psathas, G. (1998). On multiple realities and the world of film. In L. Embree (Ed.), Alfred Schutz's "sociological aspect of literature": Construction and complementary essays (pp. 219-235). Dordrecht: Kluwer Academic Publishers.

Psathas, G. (2014). Goffman and Schutz on multiple realities. In M. Staudigl \& G. Berguno (Eds.), Schutzian phenomenology and hermeneutic traditions (pp. 201-221). Dordrecht: Springer.

Schutz, A. (1962a). On multiple realities. In M. Natanson (Ed.), Collected papers, Vol. I: The problem of social reality (pp. 207-259). The Hague: Nijhoff.

Schutz, A. (1962b). Choosing among projects of action. In M. Natanson (Ed.), Collected papers, Vol. I: The problem of social reality (pp. 67-96). The Hague: Nijhoff.

Schutz, A. (1962c). Symbol, reality and society. In M. Natanson (Ed.), Collected papers, Vol. I: The problem of social reality (pp. 287-356). The Hague: Nijhoff.

Schutz, A. (1964a). Don Quixote and the problem of reality. In A. Brodersen (Ed.), Collected papers, Vol. II: Studies in social theory (pp. 135-158). The Hague: Nijhoff.

Schutz, A. (1964b). Making music together. A study in social relationship. In A. Brodersen (Ed.), Collected papers, Vol. II: Studies in social theory (pp. 159-178). The Hague: Nijhoff.

Schutz, A. (1964c). The stranger. An essay in social psychology. In A. Brodersen (Ed.), Collected papers, Vol. II: Studies in social theory (pp. 91-105). The Hague: Nijhoff.

Schutz, A. (1967). The phenomenology of the social world. Geneva, NY: Northwestern University Press.

Schutz, A. (2011). Reflections on the problem of relevance. In L. Embree (Ed.), Collected papers, Vol. V: Phenomenology and the social sciences (pp. 93-199). Dordrecht: Springer.

Schutz, A., \& Luckmann, T. (1973). The structures of the life-world (Vol. 1). Evanston, IL: Northwestern University Press.

Schutz, A., \& Luckmann, T. (1989). The structures of the life-world (Vol. 2). Evanston, IL: Northwestern University Press.

Sebald, G. (2011). Crossing the finite provinces of meaning. Experience and metaphor. Human Studies, 34(4), 341-352.

Spickard, J. V. (1991). Experiencing religious rituals. A Schutzean analysis of Navajo ceremonies. Sociological Analysis, 52(2), 191-204.

Van Gennep, A. (1960). The rites of passage. London: Routledge \& Kegan Paul.

Wagner, G., \& Weiss, G. (Eds.). (2011). A friendship that lasted a lifetime: The correspondence between Alfred Schütz and Eric Voegelin. Columbia, MO: University of Missouri Press.

Weber, M. (2005). The protestant ethic and the spirit of capitalism. London/New York: Routledge. 